\title{
WHY IS IT NOT SEE EVERYTHING A-50 - HEAVENLY EYES AND EARS OF RUSSIA
}

\author{
Milan DŽUNDA, Peter DZUROVČIN* \\ Department of Air Transport Management, Faculty of Aeronautics, TUKE, Rampová 7, 04121 Kosice \\ *Corresponding author. E-mail: peter.dzurovcin@tuke.sk
}

\begin{abstract}
In this paper we analyze of the A 50 air defense system. Attention we paid to shielding the radar signals of the " Шмель " system. We present the individual stages of the construction of the system, its purpose and basic technical data. At the beginning of 2011, the Russian aircraft detection and guidance systems entered a new era thanks to the commissioning of the long-awaited modernized A50U OKB Beriev aircraft. By mid-2013, two A-50Us were in operation, the third was expected by the end of the year and the fourth is planned to be commissioned in 2014. The modernization of the A-50 can be seen as a huge leap forward for the Air Force, which finally put computers into operation 21st century display systems paired with powerful radar.
\end{abstract}

Keywords: fuselage, air force, shielding of radar

\section{INTRODUCTION}

An ambitious development program for the A-50, was launched in 1973 on the IL-76MD military transport aircraft [12 to 23]. IL-76MD is a modern aircraft that meets ICAO requirements [6 to 11]. On the A-50 was installed radio engineering complex " Шмель ", developed at the Moscow Scientific Research Institute of Instrument (NII-17, now OAO "Concern" Vega "). In Taganrog, on the basis of IL-76MD manufactured by the Tashkent aircraft factory, three prototypes for the test program were manufactured. The prototype A-50 made its first flight on December 19, 1978 in Taganrog without installed target equipment.

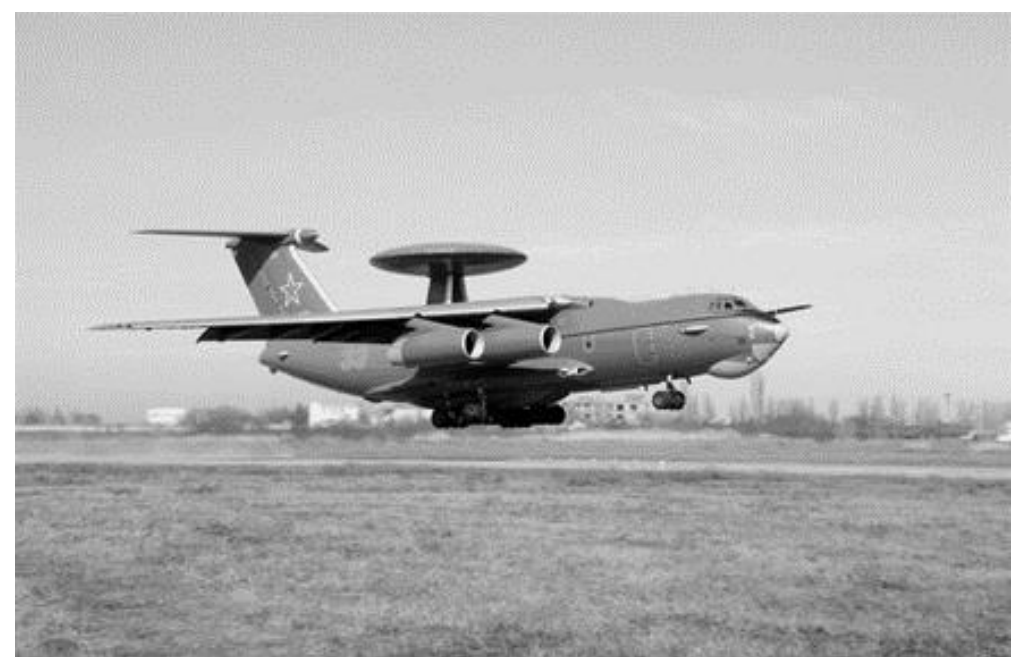

Figure 1 A-50 one of the most important systems in Russian military aviation [12]

The development and testing of a new type has become a long matter. This became especially apparent during the joint state tests, mainly due to the low reliability of the sophisticated equipment of the " Шмель " system, caused by the low quality and low performance of Soviet electronics. The development and testing of a new type has become a long matter. This became especially apparent 
during the joint state tests, mainly due to the low reliability of the sophisticated equipment of the " Шмель " system, caused by the low quality and low performance of Soviet electronics.

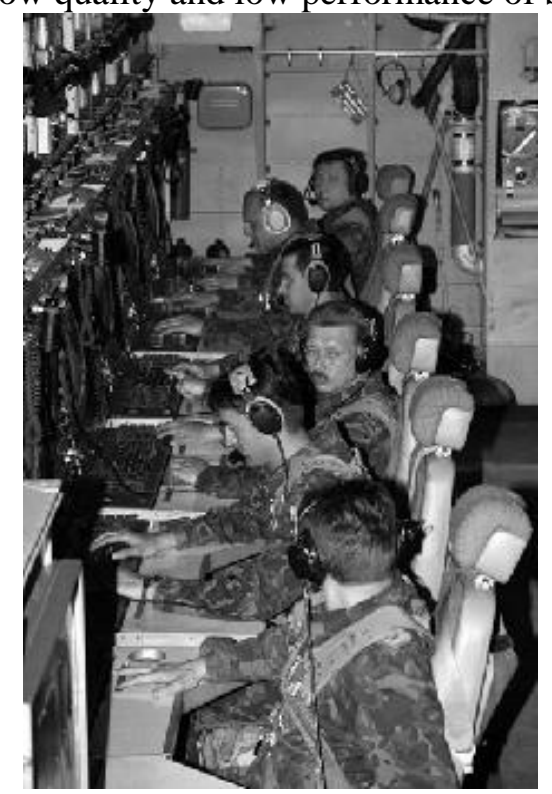

Figure 2 Work desks of guidance and tracking operators in the non-modernized A-50 [12]

The development and testing of a new type has become a long matter. This became especially apparent during the joint state tests, mainly due to the low reliability of the sophisticated equipment of the " Шмель " system, caused by the low quality and low performance of Soviet electronics. The A-50 was approved for full-scale serial production in December 1984. Trial operation of the type began in the same year, when one aircraft was relocated to Severomorsk-1, an airfield near Murmansk, on the Kola Peninsula, from which it flew from 1985 to 1988. In 1989 it was possible to integrate the complex into the air defense command and control system. Between 1985 and 1992, 25 aircraft were built, including three prototypes. Aircraft produced at the Tashkent Aircraft Plant were transported to Taganrog, where the " Шмель " complex was installed on them. The main objective of the A-50 was the control and guidance of air defense fighters using the A-50 locator. In October 1989, the A-50 regiment was relocated to the Berezovka airfield, on the Kola Peninsula, beyond the Arctic Circle. This allowed the A-50 to cover the entire territory of the USSR - from Kaliningrad in the west, to Kamchatka in the east, and from Novaya Zemlya in the north, to the North Caucasus in the south.

Currently, the group have 9 aircraft in readiness for departure, or on a mission, at any time. The importance of the A-50 for the Air Force is explained by the lack of continuous coverage of the radar field in the remote territories of the Russian north, where the capabilities of the A-50 are used to close such "holes". A-50 aircraft were actively used during both Chechen wars, in 1994-1995 and 1999-2000, as well as during the war with Georgia over the territory of South Ossetia in August 2008.

\section{MODERNIZATION A 50}

The installation of a huge radar fairing on the back of the A-50 led to the need for serious changes in the fuselage design, necessary in order to maintain the stability and controllability of the aircraft. The control of the A-50 is noticeably different from the IL-76MD, especially when landing. To provide the locator with power, the AI-24UBE generator, generating $480 \mathrm{~kW}$, was installed on the A-50. The generator is installed in the fairing of the chassis on the port left side. At the base of the keel there is a large air intake designed to cool various electronic equipment. The sealed rear cockpit which is protected against radiation protection has 10 workstations for operators and is filled with racks with

electronic equipment. Radiation protection includes a metal mesh fixed inside the fuselage and goldplated portholes. The total weight of the electronic equipment in the rear cabin is 10 tons, and there is no space left for the toilet, while the total weight of the equipment (including the locator) reaches 20 
tons. Before turning on the equipment, which follows after starting the engines on the ground, it is required to set the temperature in the rear cocpit to 15 degrees.

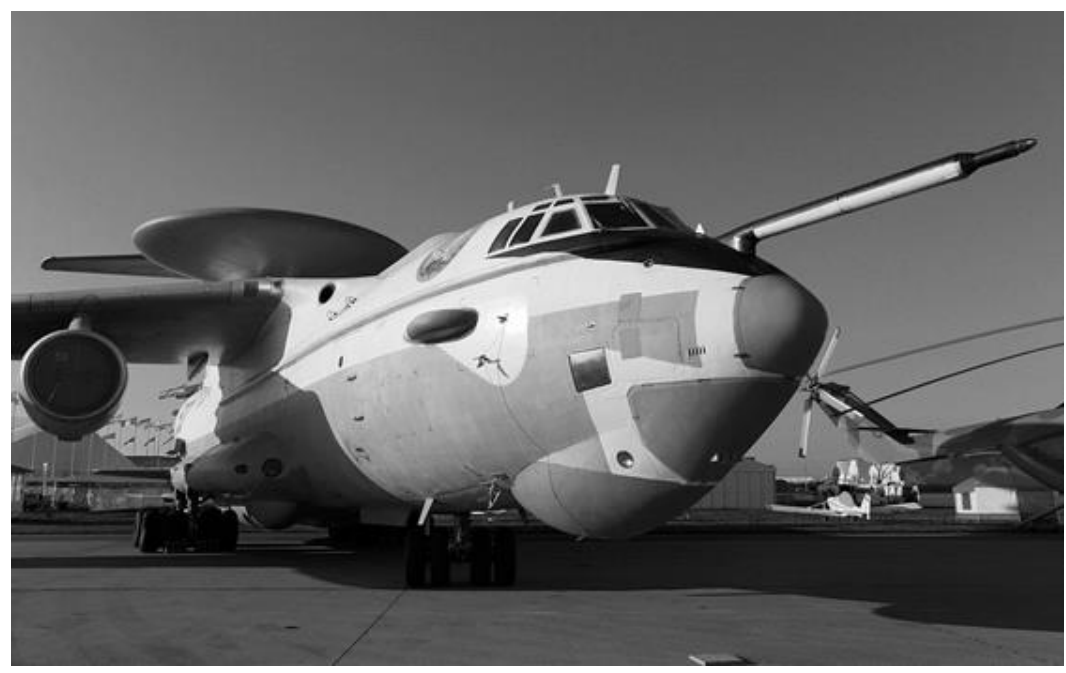

Figure 3 View of the modernized A 50 from the front [12]

This requires long-term cooling in the summer and heating in the winter. The radar turns on after climbing $3000 \mathrm{~m}$. The antenna of the locator is located in a large "plate" of the fairing, with a diameter of $10.2 \mathrm{~m}$ and a maximum thickness of $2.5 \mathrm{~m}$, mounted on two pylons placed above the trailing edge of the wing. The fairing is located at a distance of $3.2 \mathrm{~m}$ above the fuselage, near the center of gravity of the aircraft. The radar fairing is made of two translucent fiberglass sections and a metal box, in which both the main antenna of the locator and the antenna of the friend-or-foe identification system are installed. The profile of the pylons was chosen so that they improve the longitudinal stability of the aircraft.

\section{CALCULATION OF THE RADAR SHADOW LENGTH " ШMEЛЬ " SYSTEM}

As mentioned, the A 50 aircraft is capable of detecting low flying targets and ground objects.

In [ 1 to 5$]$ it is stated that obstacles that are in direct visibility of the radar cause shielding of radar signals. As a result, the radar cannot detect air and ground targets behind obstacles. We are interested in what distance the " Шмель " system is unable to detect low altitude and ground targets due to the radar shadow caused by the fuselage. First we examine the shielding of radar signals in the vertical plane. This analysis is based on the dimensions of the A 50. We assume horizontal flight A 50. The other dimensions in (m) used in the calculation are shown in Fig. 4 and 5.

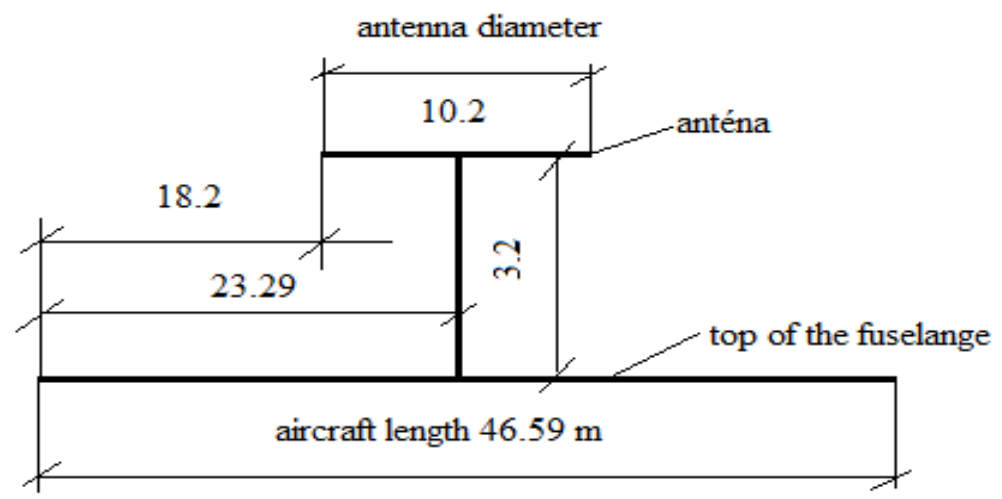

Figure 4 Selected dimensions A 50 used in the calculation 
Selected aircraft dimensions [12 to 23]:

- aircraft length $46.59 \mathrm{~m}$,

- the diameter of the mid-section is $4.8 \mathrm{~m}$,

- antenna diameter $10.2 \mathrm{~m}$

- height of the antenna above the fuselage $3.2 \mathrm{~m}$

- Aircraft length 46.59

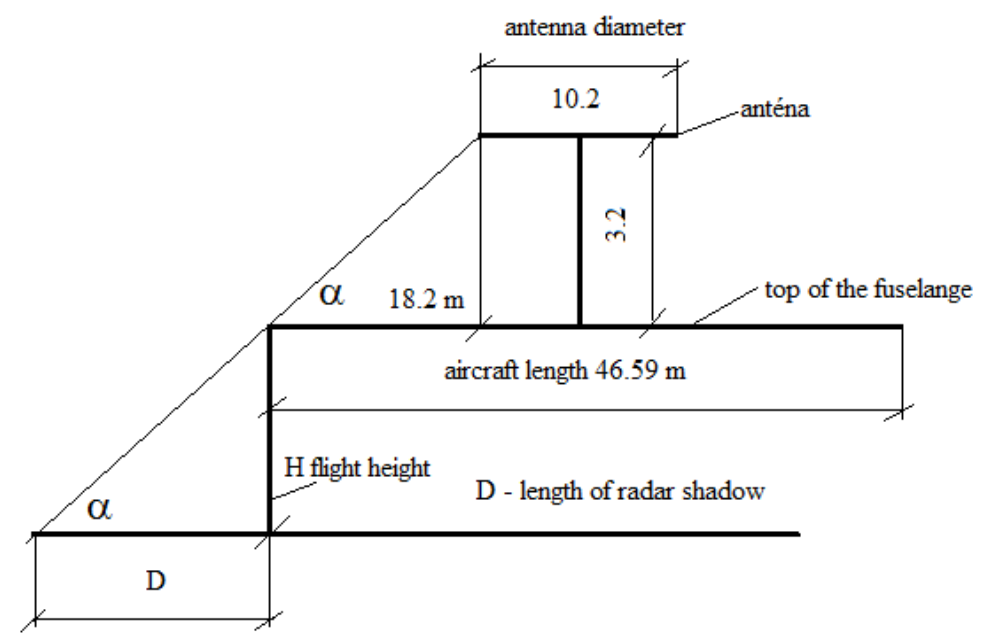

Figure 5 Calculation of the radar shadow length

In calculating the length of the radar shadow we proceeded as follows. First we calculate the angle $\alpha$ : $\alpha=\operatorname{arctg}(3.2 / 18.2)=9.972^{\circ}$

Then we calculate the unknown $\mathrm{D}$ according to the relation:

$$
D=H / \operatorname{tg} \alpha
$$

From the above relationship it is clear that $\mathrm{D}$ depends on the flight height $\mathrm{H}$ A 50 . Because the radar turns on after climbing on $3000.0 \mathrm{~m}$ we calculate the length of the radar shadow for heights of 300.0 to 12000.0 m. The results of the radar shadow calculation are shown in Fig. 6 and 7.

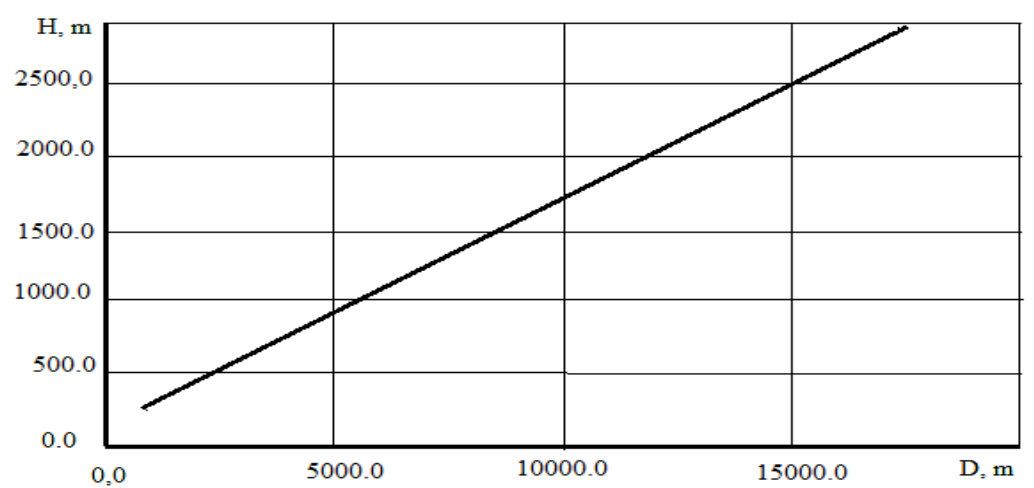

Figure 6 The radar shadow length for flight altitude A 50300.0 to $3000.0 \mathrm{~m}$

In Figure 6 are shows the results calculates of the radar shadow length for flight altitude A 50300.0 to $3000.0 \mathrm{~m}$. In Fig. 6 we see, that for flight height A 50300.0 to $3000.0 \mathrm{~m}$, the radar shadow length varies from $1700 \mathrm{~m}$ to $17000 \mathrm{~m}$. 


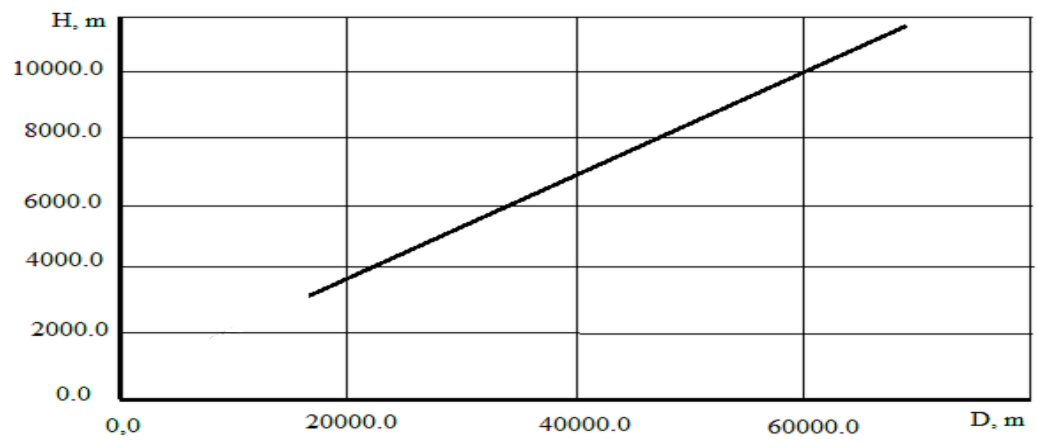

Figure 7 The radar shadow length for flight altitude A 503000.0 to $12000.0 \mathrm{~m}$

In Fig. 7 are shows the results calculates of the radar shadow length for flight altitude A 503000.0 to $12000.0 \mathrm{~m}$. For flight height A 503000.0 to $12000.0 \mathrm{~m}$, the radar shadow length varies from 17000.0 $\mathrm{m}$ to $68250.0 \mathrm{~m}$. Next we examine the shielding of radar signals in the horizontal plane. This analysis is based on the dimensions of the A 50, which ones listed at the beginning of this chapter. We assume horizontal flight A 50. The dimensions in (m) used in the calculation are shown in Fig. 8.

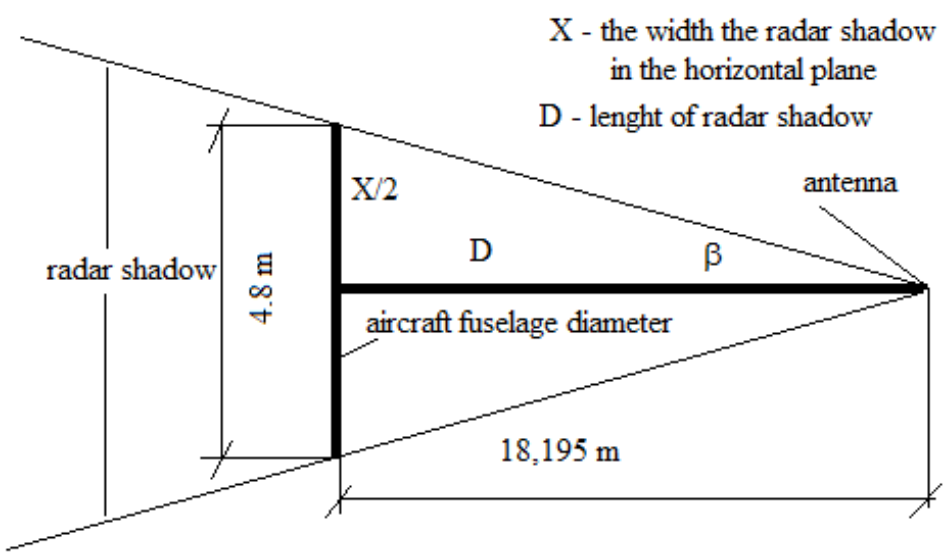

Figure 8 Calculation of the width the radar shadow in the horizontal plane

In calculating the width of the radar shadow we proceeded as follows. First we calculate the angle $\beta$ : $\beta=\operatorname{arctg}(2.4 / 18.2)=7.51418^{\circ}, \operatorname{tg} \beta=2.3021 .10^{-3}$

Then we calculate the unknown $\mathrm{X}$ according to the relation:

$$
X=2 . D \cdot \operatorname{tg} \beta
$$

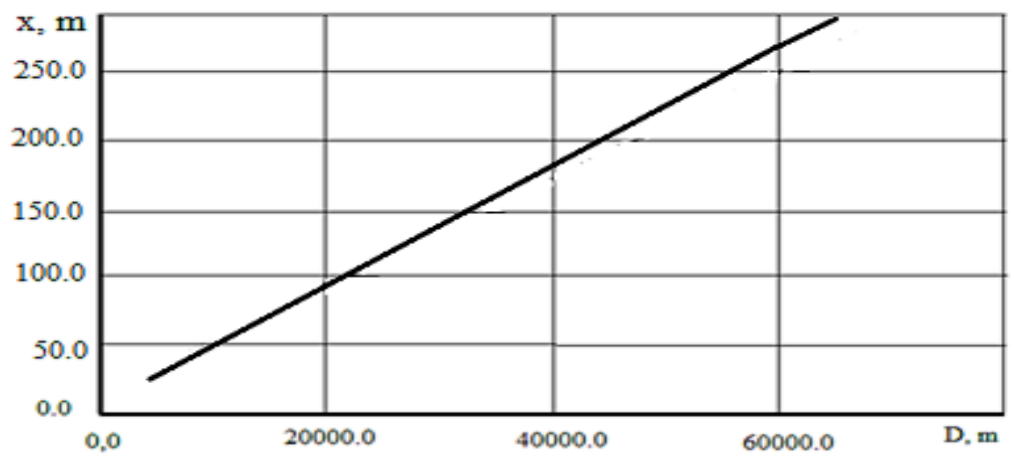

Figure 9 Calculation results of the width the radar shadow in the horizontal plane 
We calculate the width of the radar shadow for the distance of the aircraft to the target $\mathrm{D}$ equal to 1000.0 to $60000.0 \mathrm{~m}$. The results of the radar shadow calculation are shown in Fig. 9.

In Fig. 9 are shows the results calculates of the width the radar shadow in the horizontal plane for the distance of the aircraft to the target D equal to 1000.0 to $60000.0 \mathrm{~m}$. Calculation results confirmed that the radar shadow in the horizontal plane depends on the distance of the aircraft to the target $\mathrm{D}$. The width of the radar shadow varied from $4.6 \mathrm{~m}$ to $280.0 \mathrm{~m}$. Calculation results confirmed that if " Шмель " wants to detect targets that are in the direction of flight A50 at low altitudes and distances from it, then the A50 pilot must choose appropriate flight mode.

\section{COMPOSITION OF ELECTRONIC SYSTEMS A 50}

The three-coordinate radar is the heart, eyes and brain of the " Шмель " complex. It uses a phased array with mechanical scanning and rotates at a frequency of 12 revolutions per minute. Despite its age, the radar has impressive capabilities to detect and track small and low-flying aircraft. It is claimed that the bumblebee centimeter radar " Шмель " is capable of detecting high-altitude targets such as a bomber or transport aircraft at a distance of $650 \mathrm{~km}$, and fighters at a distance of $230 \mathrm{~km}$ at low and $300 \mathrm{~km}$ at high altitude. Cruise missiles with an flat of $1 \mathrm{~m} 2$ can be detected at a distance of $215 \mathrm{~km}$, and large ships at a distance of the radar horizon, which is located at $400 \mathrm{~km}$. The detection accuracy is $2.5 \mathrm{~km}$. The A-50 radar is also capable of detecting radiocontrast ground targets, for example, a ballistic missile launcher can be detected at a distance of $300 \mathrm{~km}$, and a tank column at a distance of $250 \mathrm{~km}$.

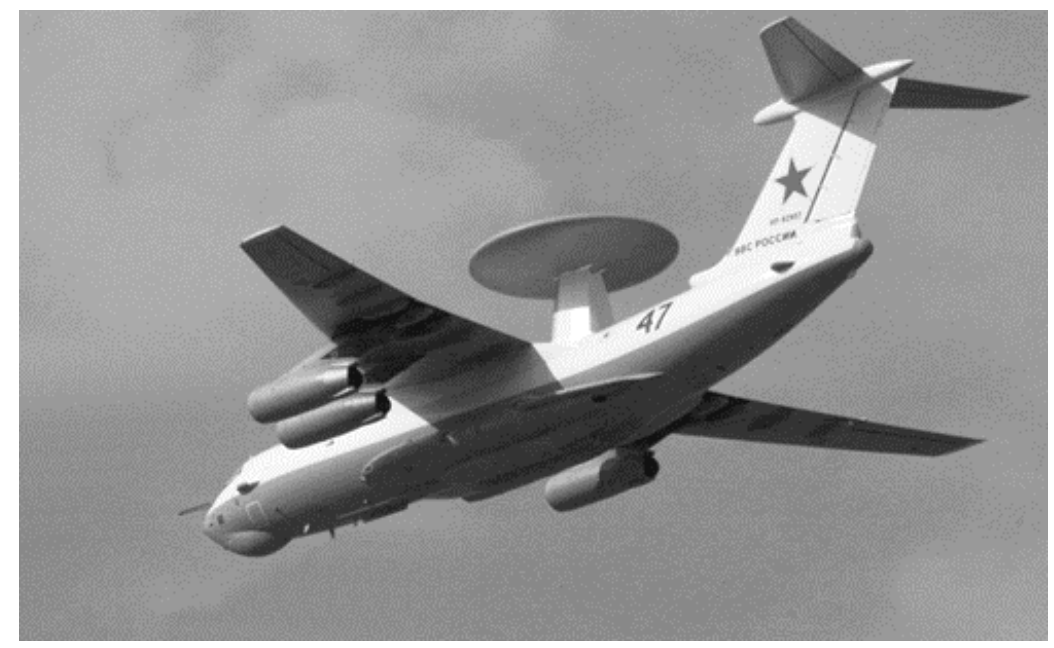

Figure 10 A-50 Heavenly eyes and ears of Russia [12]

The " Шмель , radar, replaced by the improved " Шмель -М " radar in the late 80s and early 90s, can track from 50 to 60 targets at a time. The current." Шмель -М " guides 140 targets and can direct up to 12 of its fighters, providing guidance information over data transmission channels. The radar operates in two main modes: quasi-constant and pulsed. The first is used to detect and track aerial targets, while the second is used to detect sea and ground targets. The air-to-air operating mode uses Doppler filtering of the reflected signal to isolate the mark from the target against the background of noise from the earth's surface when detecting and tracking low-flying targets. The system provides further processing and grouping of the signal in order to determine the azimuth, altitude, range and direction of the target. The " Шмель -M " computing system consists of four digital processors BCVMA-50, connected into one system, operating in a fault-tolerant mode. This means that a failure of one of the processors will not lead to a failure of the entire system. The system will continue to operate, although its computing capabilities will be limited. Processors process data in real time, providing target detection, recognition, display, data transmission over communication channels and the generation of guidance commands for interceptors. The display system is equipped with circular indicators on the operator panels and provides the display of a moving picture in a fixed coordinate system. This means 
that the A-50 and detected targets are displayed as moving objects relative to a fixed point on the ground. The A-50 is also equipped with electronic intelligence systems to detect sources of radio emission, such as radars and radio stations, and determine their location in a wide range of radiation frequencies. This information is still classified, but it is believed that the A-50 intelligence systems are capable of intercepting negotiations at frequencies from 50 to $500 \mathrm{MHz}$, while electronic intelligence systems cover the range from 0.5 to $18 \mathrm{GHz}$. The A-50 is also equipped with radar suppression systems for its own protection, as well as radiation warning system receivers and jamming units mounted on the sides of the rear of the fuselage. The communication equipment of the aircraft includes a large number of direct visibility data channels for exchanging data with various services and secure communication channels in the HF and VHF bands. HF communication is used at ranges up to $2000 \mathrm{~km}$, VHF and line of sight channels at distances up to $400 \mathrm{~km}$. Radio transmitters use antennas mounted on the fuselage taking into account the electromagnetic compatibility of various emitting systems.

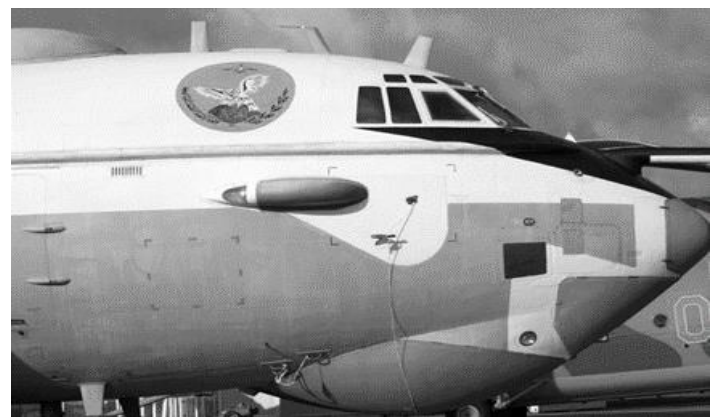

Figure 11 Detailed view of the modernized A 50 from the front [12]

In addition, there is also a satellite communications terminal using a large antenna located under the fairing above the central wing section, designed to communicate with the command center at distances exceeding $2000 \mathrm{~km}$. A-50 is just an integral part of an integrated air defense system. It has the ability to detect, identify and determine the coordinates of air, land and sea targets and transfer them to the picture of land and sea control centers. Operators on board the A-50 have the task of controlling their fighters using data and voice channels. They can also control strike forces or fighters for air superiority in disputed airspace. Other tasks of the A-50 are to support important targets, such as airplanes of the heads of state, or airplanes carrying especially important cargoes.

The aircraft can also serve as an early warning tool or a remote scanning platform, providing a recognized picture of the air situation ground control centers responsible for overall combat control. The A-50 can perform these tasks autonomously, acting as a control system cell with its own rights, or as part of a larger system using information transmitted over data channels and radio. It can also perform both tasks simultaneously. The flight crew of the A-50 consists of two pilots (commander and co-pilot), navigator, flight engineer and radio operator. The 10-man tactical crew in the rear compartment includes a crew commander, a senior fighter guidance operator, two guidance operators, a senior tracking operator, two tracking operators, a system engineer, a radar engineer, and a communications systems engineer.

\section{CONCLUSION}

In this paper based on available information we analyze of the A 50 air defense system. The modification of the A-50 systems, begun in the late $90 \mathrm{~s}$, was designed to add new features, such as reliable detection and tracking of low-flying helicopters, and the integration of modern data exchange terminals for ground users of the system to expand the circle of users to the division level. Calculation results listed in Chapter 3 confirmed that if " Шмель " wants to detect targets that are in the direction of flight A50 at low altitudes and distances from it, then the A50 pilot must choose appropriate flight mode. Another task of modernization was combining target data received from the radar with electronic and radio reconnaissance data in order to achieve more reliable target identification. Another task was to ensure the simultaneous operation of two or more A-50s, with one aircraft as a leader, and the other as 
a slave, providing the leader with a picture of the radar situation and providing guidance and air traffic control on the instructions of the A-50 leader. These improvements were achieved in the process of modernization of the A-50U, which began at the beginning of the 2000th year, the tests on which continued until 2009 on the prototype with tail number "33 red" (manufacturer index - 58-05). Almost all obsolete equipment of the 80 s was replaced with modern equipment. The final report on the completion of the A-50U tests was signed by the Air Force Commander-in-Chief, Colonel-General Alexander Zelin in October 2009. The first modernized "47 Red" aircraft, state registration RF-92957, manufacturer index 40-05, was transferred to the Air Force on October 31, 2011.

\section{References}

[1] Dzunda, M. - Hrban, A. Accuracy of the passive tracking systems. Conference: 12th International Conference on Microwaves and Radar (MIKON98) Location: KRAKOW, POLAND Date: MAY 20-22, 1998, Pages: 216-220

[2] Dzunda, M. - Kotianova, N. Selected Aspects of Applying Communication Technology to Air Transportation. Conference: International Conference on Computer Science and Information Engineering (CSIE) Location: Bangkok, THAILAND Date: JUN 28-29, 2015, Pages: 1-7

[3] Džunda, M. - Cséfalvay, Z. Selected methods of ultra-wide radar signal processing. Marine Navigation and Safety of Sea Transportation: Advances in Marine Navigation. TRANSNAV 2013, pp. 239-242

[4] Džunda, M. - Dzurovcin, P. - Cekanova, D. Operational economic aspects of warning collision systems for helicopters. Transport Means - Proceedings of the International Conference 2018-October, pp. 1151-1155

[5] Dzunda, M. - Kotianova, N. - Pulis, P. et al.: Selected Aspects of the Windmill Construction Impact on Air Traffic Safety. Conference: International Conference on Power, Energy Engineering and Management (PEEM) Location: Bangkok, THAILAND Date: JAN 24-25, 2016, Pages: 290-294

[6] Ďurčo, S., Sabo, J., Rozenberg, R., Miženková, Ž. Means of CPDLC using with ATC procedures in terminal maneuvering area In: 2017 Distance Learning, Simulation and Communication 2017. - Brno : University of Defence, 2017 p. 62-67. - ISBN 978-80-7231-415-7

[7] A. Tobisová, R. Rozenberg, J. Vágner, and E. Jenčová, Social network applicability in air transport, Transport Means - Proceedings of the International ConferenceVolume 2017-September, 2017, 21st International Scientific Conference Transport Means 2017; Rest House "Azuolynas"L. Rezos Str. 54Juodkrante; Lithuania; 20 September 2017 through 22 September 2017, p. 1040-1044

[8] Zgodavová, Z., Rozenberg, R., Szabo, S. Analysis of Point-to-Point versus Hub-and-Spoke airline networks In: New Trends in Aviation Development 2018: The 13. International Scientific Conference. Danvers (USA): Institute of Electrical and Electronics Engineers 158-162. - ISBN 978-15386-7917-3

[9] Kal'avský, P., Rozenberg, R., Petríček, P., Socha, V., Socha, L. Rope procedures for extraction and insertion of persons used by helicopter emergency medical service In: Research and Education in Aircraft Design 2018: conference proceedings. - Brno: Vysoké učení technické v Brně s. 76-84. - ISBN 978-80-214-5696-9

[10] Koščák, P., Jenčová, E., Galanda, J., Liptáková, D. Airports SMS Penetration with Occupational Health Protection. In: New Trends in Aviation Development 2019. Danvers (USA) : Institute of Electrical and Electronics Engineers, 2019. s. 96-101. ISBN 978-1-7281-4078-0

[11] Keselova, M., Liptakova, D. Galanda, J., Koscak, P. The current impact of aviation performance on carbon dioxide production. In: Proceedings of the International Scientific Conference Modern Safety Technologies in Transportation 2019. Košice: Technical University of Košice, Nov. 28 - 29, 2019. p. 80-84. ISBN 978-1-7281-5082-6.

[12] http://www.airforce.ru/content/okb-berieva/1434-50-nebesnye-glaza-i-ushirossii/\#comments

[13] https://militaryexp.com/samolet-il-76-harakteristiki-i-modifikatsii/

[14] Beriev A-50 Mainstay

[15] $\quad \underline{\text { A-50 Mainstay Airborne Early Warning and Control Aircraft (AEW\&C), Russia }}$ 
[17] Beriev A-50 Mainstay

[18] Российская авиация в Чеченской войне

[19] Россия начала применять в Сирии самолеты ДРЛО и управления А-50

[20] Third updated Russian A-50 AWACS

[21] Russian Air Force Shows Upgraded Awacs, and Plans New One

[22] Индия заказала у РФ два самолета дальнего радиолокационного обнаружения

[23] Четвертый модернизированный самолет А-50У

Received 12, 2019, accepted 07, 2020

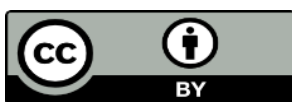

Article is licensed under a Creative Commons Attribution 4.0 International License 